\title{
Return to Capital in a Real Business Cycle Model
}

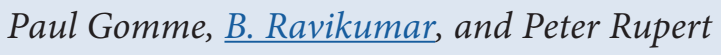

Can the neoclassical growth model generate fluctuations in the return to capital similar to those observed in the United States? Equating stock market returns with the return to capital, the bulk of the literature concludes that it cannot. This article makes two contributions. First is an equivalence for the neoclassical growth model between a stock market return and a return based on income and capital stock data. While the stock market return is extremely volatile, the income-based return is not. Second is the finding that the neoclassical growth model with shocks to labor productivity alone can account for the bulk of the observed volatility of the income-based return to capital (expressed relative to the volatility of income) but little of the volatility of the stock market return. Simultaneously explaining the volatility of the two measures of the return to capital within the neoclassical model will require a theory of the stock market that breaks our return-equivalence results. (JEL E01, E37, O40)

Federal Reserve Bank of St. Louis Review, Fourth Quarter 2017, 99(4), pp. 337-50.

https://doi.org/10.20955/r.2017.337-350

\section{INTRODUCTION}

This article investigates whether a real business cycle (RBC) model is consistent with the observed asset return. Previous attempts to answer this question have used the Standard and Poor's (S\&P) 500 return to measure the asset return (see, for example, Boldrin, Christiano, and Fisher, 2001). We construct the return to capital from the National Income and Product Accounts (NIPA) and use it to measure the asset return.

We exploit the fact that, in the RBC model, the return to a unit of physical capital and the financial return to equity are the same. This equivalence implies that the model's implications can be "tested" against the observed NIPA return to capital or the observed financial return. We conduct the test using the former.

While the theory says that these two returns should be identical, in the data they are not. The percent standard deviation of the S\&P 500 quarterly return is 25 times more volatile than our constructed return to capital (Figure 1). 1

Paul Gomme is a professor of economics at Concordia University, Montreal, and a research fellow at CIREQ; he acknowledges financial support from the Social Sciences and Humanities Research Council of Canada (grant number 435-2016-1388). B. Ravikumar is a vice president and deputy director of research at the Federal Reserve Bank of St. Louis. Peter Rupert is a professor of economics at the University of California, Santa Barbara.

○ 2017, Federal Reserve Bank of St. Louis. The views expressed in this article are those of the author(s) and do not necessarily reflect the views of the Federal Reserve System, the Board of Governors, or the regional Federal Reserve Banks. Articles may be reprinted, reproduced, published, distributed, displayed, and transmitted in their entirety if copyright notice, author name(s), and full citation are included. Abstracts, synopses, and other derivative works may be made only with prior written permission of the Federal Reserve Bank of St. Louis. 
Figure 1

\section{Pre-Tax Real Returns to the S\&P 500 and Capital}

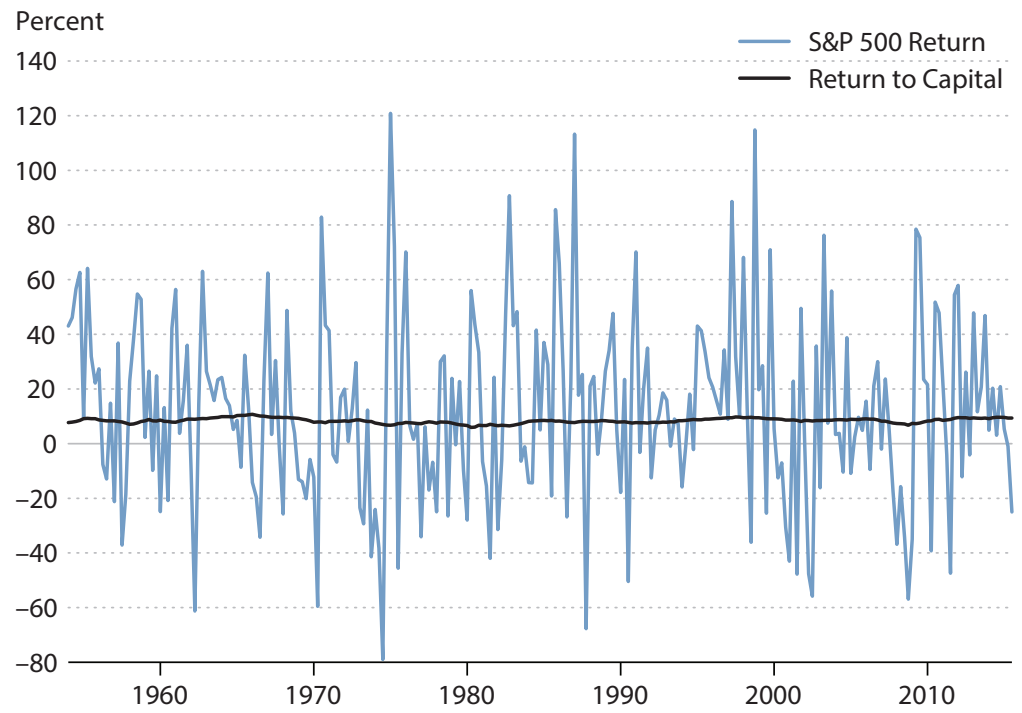

SOURCE: Pre-tax return to capital: Authors' calculations as described in the text. S\&P 500 return: Bloomberg.

As is traditional in the RBC literature, the only shock in the model is to labor productivity. In the data, there are many more shocks. To put the model on an equal footing with the data, we focus on the volatility of returns relative to that of output. In the data, the return to capital is 6.3 times more volatile than output. In a standard RBC model, the return to capital is 3.7 times more volatile than output. In other words, the model captures almost 60 percent of the observed relative volatility. Simple variants such as higher risk aversion capture almost 100 percent of the observed relative volatility.

As can be seen from Figure 1, the success of the model in capturing the observed volatility in the return to capital necessarily implies that the model cannot account for the observed volatility in the financial return. Without a theory of the stock market that breaks the equivalence between the financial return and the return to capital, a business cycle model cannot simultaneously reconcile both returns.

\section{ENVIRONMENT}

The model we consider is standard and closely resembles that of Cooley and Prescott (1995) or, more recently, Gomme, Ravikumar, and Rupert (2011). Therefore, the description is brief; further details can be found in the articles mentioned above.

Output is produced according to a constant-returns-to-scale Cobb-Douglas production function,

$$
y_{t}=F\left(k_{t}, z_{t} n_{t}\right)=k_{t}^{\alpha}\left(z_{t} n_{t}\right)^{1-\alpha}
$$


where $k_{t}$ is the beginning-of-period capital stock, $n_{t}$ is hours worked, and $z_{t}$ is labor-embodied technological change described by

$$
\ln z_{t}=\rho \ln z_{t-1}+\varepsilon_{t}
$$

where $\varepsilon_{t}$ is the innovation to technological change and has a Normal distribution with mean 0 and standard deviation $\sigma . \underline{2}$

Output can be converted into either consumption, $c_{t}$, or investment goods, $i_{t}$ :

$$
c_{t}+i_{t}=y_{t}
$$

The capital stock evolves according to

$$
k_{t+1}=(1-\delta) k_{t}+i_{t}
$$

where $\delta$ is the depreciation rate of capital.

The representative household has preferences over streams of consumption, $c_{t}$, and leisure, $\ell_{t}$ :

$$
E_{0} \sum_{t=0}^{\infty} \beta^{t} U\left(c_{t}, \ell_{t}\right)
$$

The period utility function has the functional form

$$
U(c, \ell)=\left\{\begin{array}{ll}
\frac{\left[c \ell^{\omega}\right]^{1-\gamma}}{1-\gamma} & \text { if } 0<\gamma<1 \text { or } \gamma>1, \\
\ln c+\omega \ln \ell & \text { if } \gamma=1 .
\end{array}\right\} .
$$

The household allocates its 1 unit of time between leisure, $\ell_{t}$, and work, $n_{t}$ :

$$
\ell_{t}+n_{t}=1
$$

We show the equivalence between the return to physical capital and the return to an appropriate financial asset by describing the problem through two separate decentralizations. In the first, households make capital investment decisions; in the second, firms make those decisions.

\subsection{Decentralization: Households Make Investment Decisions}

The household's problem is to choose contingent sequences of consumption, $c_{t}$, work, $n_{t}$, and capital, $k_{t+1}$, so as to maximize lifetime utility, equation (3), taking as given the wage rate, $w_{t}$, and the rental rate for capital, $r_{t}$, where each are measured in units of the consumption good in period $t$.

Formally, the representative household's problem is given by

$$
\max _{\left\{c_{t}, n_{t}, k_{t+1}\right\}_{t=0}^{\infty}} E_{0} \sum_{t=0}^{\infty} \beta^{t} U\left(c_{t}, 1-n_{t}\right)
$$


subject to

$$
c_{t}+k_{t+1}-(1-\delta) k_{t}=r_{t} k_{t}+w_{t} n_{t}
$$

The representative firm solves a sequence of static problems:

$$
\max _{k_{t}, n_{t}} F\left(k_{t}, z_{t} n_{t}\right)-\left(r_{t} k_{t}+w_{t} n_{t}\right)
$$

Note that the price of output in period $t$ is the same as that of the consumption good in that period, so the profits of the firm in period $t$ are denoted in units of the consumption good in period $t$. In this decentralization, it is clear from the firm's problem that factor prices satisfy

$$
\begin{gathered}
r_{t}=F_{1}\left(k_{t}, z_{t} n_{t}\right), \\
w_{t}=z_{t} F_{2}\left(k_{t}, z_{t} n_{t}\right) .
\end{gathered}
$$

Owing to constant returns to scale of the production function, the profits of the firm are equal to zero every period. From the household's problem,

$$
\begin{aligned}
& U_{1}\left(c_{t}, 1-n_{t}\right)=\eta_{t} \\
& \eta_{t}=\beta E_{t} \eta_{t+1}\left[F_{1}\left(k_{t+1}, z_{t+1} n_{t+1}\right)+1-\delta\right] \\
& U_{2}\left(c_{t}, 1-n_{t}\right)=z_{t} F_{2}\left(k_{t}, z_{t} n_{t}\right) \eta_{t},
\end{aligned}
$$

where $\eta_{t}$ is the Lagrange multiplier associated with the household's constraint in period $t$.

In equilibrium, the gross real rate of return to capital in this decentralization is

$$
F_{1}\left(k_{t+1}, z_{t+1} n_{t+1}\right)+1-\delta
$$

A unit of capital in period $t$ costs the household 1 unit of the consumption good. The payoff for the household in period $t+1$ is as follows: The unit of capital produces $F_{1}\left(k_{t+1}, z_{t+1} n_{t+1}\right)$ units of the consumption good, and the left-over capital is worth $1-\delta$ units of the consumption good. So, the return to capital is $F_{1}\left(k_{t+1}, z_{t+1} n_{t+1}\right)+1-\delta$.

\subsection{Decentralization: Firms Make Investment Decisions}

In this subsection, it is firms that make capital investments and the household's problem is static, except for asset holdings, such as shares of firms. The firm's payoff (or dividend) is defined as

$$
d_{t}=F\left(k_{t}, z_{t} n_{t}\right)-w_{t} n_{t}-i_{t}
$$

and it accumulates capital according to equation (2).

Firms choose $\left\{d_{t}\right\}_{t=0}^{\infty}$ to maximize

$$
E_{0} \sum_{t=0}^{\infty} \lambda_{t} d_{t}
$$


subject to equation (2) and equation (6), where $\lambda_{t}$ is the time-zero price of a unit of consumption good in period $t$.

Substituting the constraints into the firm's objective function, the first-order conditions with respect to $n_{t}$ and $k_{t+1}$ are

$$
\begin{gathered}
z_{t} F_{2}\left(k_{t}, z_{t} n_{t}\right)=w_{t} \\
\lambda_{t}=E_{t} \lambda_{t+1}\left[F_{1}\left(k_{t+1}, z_{t+1} n_{t+1}\right)+1-\delta\right] .
\end{gathered}
$$

The household's problem is to

$$
\max _{\left\{c_{t}, n_{t}, \phi_{t+1}\right\}} \sum_{t=0}^{\infty} \beta^{t} U\left(c_{t}, 1-n_{t}\right)
$$

subject to the present-value budget constraint

$$
\sum_{t=0}^{\infty} \lambda_{t}\left(c_{t}+p_{t} \phi_{t+1}\right) \leq \sum_{t=0}^{\infty} \lambda_{t}\left(w_{t} n_{t}+p_{t} \phi_{t}+d_{t} \phi_{t}\right)
$$

where $\phi_{t}$ is the household's number of shares in the firm at the beginning of period $t$ and $p_{t}$ is the price per share measured in units of the consumption good in period $t$. Let $\Lambda$ be the Lagrange multiplier in the present-value constraint. The first-order conditions with respect to $c_{t}, n_{t}, \phi_{t+1}$ are

$$
\begin{gathered}
\beta^{t} U_{1}\left(c_{t}, 1-n_{t}\right)=\lambda_{t} \Lambda \\
\beta^{t} U_{2}\left(c_{t}, 1-n_{t}\right)=\lambda_{t} w_{t} \Lambda \\
\lambda_{t} p_{t}=E_{t} \lambda_{t+1}\left(p_{t+1}+d_{t+1}\right) .
\end{gathered}
$$

The last equation will, in equilibrium, help price the asset. The market-clearing conditions are

$$
c_{t}+i_{t}=F\left(k_{t}, z_{t} n_{t}\right) \text { goods market }
$$

$$
\phi_{t}=1 \quad \text { asset market }
$$

for all $t$.

\subsection{Equivalence}

Note from equations (2) and (6) that

$$
d_{t+1}=F\left(k_{t+1}, z_{t+1} n_{t+1}\right)-w_{t+1} n_{t+1}-k_{t+2}+(1-\delta) k_{t+1},
$$




\section{Gomme, Ravikumar, Rupert}

which implies

$$
\frac{d_{t+1}+k_{t+2}}{k_{t+1}}=\frac{F\left(k_{t+1}, z_{t+1} n_{t+1}\right)-w_{t+1} n_{t+1}}{k_{t+1}}+1-\delta .
$$

Since $F$ is a constant-returns-to-scale production function, Euler's theorem says that

$$
F\left(k_{t}, z_{t} n_{t}\right)=F_{1}\left(k_{t}, z_{t} n_{t}\right) k_{t}+F_{2}\left(k_{t}, z_{t} n_{t}\right) z_{t} n_{t}
$$

so using the equilibrium wage in equation (7),

$$
\frac{d_{t+1}+k_{t+2}}{k_{t+1}}=F_{1}\left(k_{t+1}, z_{t+1} n_{t+1}\right)+1-\delta .
$$

Thus, we can rewrite equation (8) as

$$
\lambda_{t}=E_{t} \lambda_{t+1}\left(\frac{d_{t+1}+k_{t+2}}{k_{t+1}}\right)
$$

or

$$
\lambda_{t} k_{t+1}=E_{t} \lambda_{t+1}\left(k_{t+2}+d_{t+1}\right)
$$

Comparing the last equation with equation (11) gives $p_{t}=k_{t+1}$.

Thus, we can rewrite equation (14) as

$$
\frac{d_{t+1}+p_{t+1}}{p_{t}}=F_{1}\left(k_{t+1}, z_{t+1} n_{t+1}\right)+1-\delta .
$$

Equation (15) is the equivalence result: The rate of return to the financial asset, the left-hand side of equation (15), is the same as the rate of return to capital, equation (5).

\section{MEASUREMENT}

In this section, we describe the empirical counterparts to our theory in the previous section. As part of this description, we construct a time series for the rate of return to capital. The sample period for the returns data is 1954:Q1-2015:Q1. Data and program files (including detailed calculations) are available at https://paulgomme.github.io.

Construction of the empirical counterparts to the model's variables follows standard procedures in the literature, such as those in Cooley and Prescott (1995) and Gomme and Rupert (2007). The NIPA are the source for much of the derivations. Variables are converted to per capita values using the civilian noninstitutionalized population aged 16 and over. Nominal variables are converted to real ones using a deflator for consumption (nondurables and services).

In the U.S. economy, the real rate of return on a representative unit of capital can be calculated by summing all of the income generated by capital and dividing by the stock of capital 
that generated the income. The income data are found in the NIPA, while the capital stock data are obtained from the Bureau of Economic Analysis.

There are several issues complicating such a calculation, however. First, we are interested in obtaining cyclical properties of the return at a quarterly frequency; unfortunately, not all of the necessary data are available quarterly. We convert from an annual to a quarterly frequency based on the methodology in Gomme, Ravikumar, and Rupert (2011).

Second, we need to attribute some of the proprietors' income to capital because some of their income is generated from capital and some from labor. The generally accepted practice for doing so is to allocate proprietors' income to capital and labor in the same proportions as calculated for the economy as a whole (see, for example, Cooley and Prescott, 1995, and Gomme and Rupert, 2007). That is, if labor's share of national income is $1-\alpha$ and capital's share is $\alpha$, we attribute the fraction $1-\alpha$ of the proprietor's income to labor and the fraction $\alpha$ to capital.

Capital income can then be written as

$$
Y_{k}=\text { NET OPERATING SURPLUS }-(1-\alpha) \text { (PROPRIETOR'S INCOME). }
$$

Net operating surplus is defined as value added minus depreciation and payments to labor.

Dividing capital income, $Y_{k}$, by the stock of capital gives the return to capital.

\subsection{The Real Return to Capital}

The standard deviation of the rate of return to capital is 10.79 percent over the period 1954:Q1-2015:Q1 (Table 1). As documented in Table 1 (and visually in Figure 1), the rate of return to capital is very smooth relative to the S\&P 500 return - the latter is about 25 times more volatile.

Several caveats are in order regarding the rate of return to capital. First, the relative price of a unit of capital declined during the sample period. Accounting for the capital gains due to changes in the relative price would affect the volatility of the return to capital. Indeed, Gomme, Ravikumar, and Rupert (2011) measure the return to capital using the relative prices from NIPA and show that the return volatility is higher when the relative price changes are taken into account. For our sample, the return volatility increases from 10.79 percent to 38.19 percent. Second, the relevant margin for the household is the after-tax return to capital, but we have abstracted from taxes in our setup. Measuring the after-tax return to capital is not as straightforward as the procedure above, but the details are provided in Gomme, Ravikumar, and Rupert (2011). Accounting for the fluctuations in tax rates increases the return volatility from 10.79 percent to 12.67 percent. Third, the financial return in Table 1 and Figure 1 is for financial claims on publicly traded corporations, so the comparable measure of return to capital might be the return to business capital instead of the return to the entire capital stock of the economy. $\underline{3}$ The volatility of the return to business capital in our sample is 12.58 percent. 


\section{QUANTITATIVE IMPLICATIONS}

\subsection{Parameters}

As has become standard in much of macroeconomics, the calibration procedure involves choosing functional forms for the utility and production functions and assigning values to the parameters of the model based on either micro-evidence or long-run growth facts. Cooley and Prescott (1995) provide an overview of the general strategy. A more detailed description of the calibration procedure can be found in Gomme and Rupert (2007).

A model period is a quarter. There are seven model parameters that need to be assigned values. The properties of U.S. Solow residuals are used to establish values of $\rho$, the autoregressive parameter for the technology shock, and $\sigma$, the standard deviation of its innovation. The coefficient of relative risk aversion, $\gamma$, is set to 1 , which is a value commonly used in the macroeconomics literature. The four remaining parameters are $\alpha$, the capital share parameter in production; $\delta$, the depreciation rate; $\beta$, the discount factor; and $\omega$, the weight on leisure in preferences. These parameters are chosen such that in the model's deterministic steady state, the model matches up with the following observations:

1. Capital's share of income is 30.43 percent.

2. The annual depreciation rate of capital is 6.76 percent.

3. The annual pre-tax return to capital is 8.39 percent.

4. Hours worked is 25.5 percent of the time endowment.

Measurement of the return to capital has already been discussed. The remaining observations are based on updates of Gomme and Rupert (2007). The calibrated parameter values are summarized in Table 2, and values for steady-state variables in the model are reported in Table 3.

The model is solved by applying a generalized Schur technique to a first-order log approximation of the decision rules around the steady state (see Klein, 2000).

\begin{tabular}{|c|c|}
\hline \multicolumn{2}{|c|}{ Parameter Values } \\
\hline$\beta$ & 0.9801 \\
\hline V & 1.0000 \\
\hline$\omega$ & 2.3636 \\
\hline$a$ & 0.3043 \\
\hline$\delta$ & 0.0174 \\
\hline$\rho$ & 0.9720 \\
\hline$\sigma$ & 0.0110 \\
\hline
\end{tabular}

\section{Table 3}

Benchmark Model's Steady State

$\begin{array}{ll}\text { Capital } & 5.1279 \\ \text { Hours } & 0.2550 \\ \text { Consumption } & 0.5465 \\ \text { Output } & 0.6355 \\ \text { Capital-output ratio } & 8.0693 \\ \text { Investment-output ratio } & 0.1400 \\ \text { Return to capital (annual, \%) } & 8.3937\end{array}$

SOURCE: Authors' calculations as described in the text. 
Gomme, Ravikumar, Rupert

\section{Table 4}

\section{Quantitative Implications of the Benchmark Model}

\begin{tabular}{|c|c|c|c|c|c|c|}
\hline & \multicolumn{3}{|c|}{ U.S. 1954:Q1-2015:Q1 } & \multicolumn{3}{|c|}{ Benchmark model } \\
\hline & $\begin{array}{l}\text { Percent } \\
\text { standard } \\
\text { deviation }\end{array}$ & $\begin{array}{l}\text { Relative } \\
\text { standard } \\
\text { deviation }\end{array}$ & $\begin{array}{l}\text { Correlation } \\
\text { with output }\end{array}$ & $\begin{array}{l}\text { Percent } \\
\text { standard } \\
\text { deviation }\end{array}$ & $\begin{array}{l}\text { Relative } \\
\text { standard } \\
\text { deviation }\end{array}$ & $\begin{array}{l}\text { Correlation } \\
\text { with output }\end{array}$ \\
\hline Output & 1.72 & 1.00 & 1.00 & 1.46 & 1.00 & 1.00 \\
\hline Consumption & 0.94 & 0.55 & 0.82 & 0.60 & 0.41 & 0.94 \\
\hline Investment & 4.90 & 2.85 & 0.90 & 7.11 & 4.87 & 0.98 \\
\hline Hours & 1.83 & 1.06 & 0.83 & 0.69 & 0.47 & 0.97 \\
\hline Productivity & 1.04 & 0.60 & 0.19 & 0.80 & 0.55 & 0.98 \\
\hline Capital & 1.40 & 0.81 & 0.26 & 0.43 & 0.55 & 0.98 \\
\hline Return to capital & 10.79 & 6.27 & 0.36 & 5.43 & 3.72 & 0.62 \\
\hline \multicolumn{7}{|c|}{$\begin{array}{l}\text { NOTE: All variables are transformed by taking their natural logarithm then applying the Hodrick-Prescott filter with a smoothing parameter of } 1,600 \text {; } \\
\text { the only exception is the return to capital, which is transformed by removing its sample mean and dividing the result by the sample mean. Relative } \\
\text { standard deviations are expressed relative to the standard deviation of output. Moments for the model are averages over 10,000 samples, each } \\
\text { sample consisting of } 245 \text { observations, the same as the number of quarters of U.S. data. }\end{array}$} \\
\hline \multicolumn{7}{|c|}{$\begin{array}{l}\text { SOURCE: Moments for the U.S. data are based on the authors' calculations as described in Gomme, Ravikumar, and Rupert (2011) and available } \\
\text { for download from paulgomme.github.io. Model moments are based on the authors' solution of the relevant model. }\end{array}$} \\
\hline
\end{tabular}

\subsection{Findings}

The business cycle moments for the United States covering the period 1954:Q1-2015:Q1 are presented in Table 4 (a more complete set of moments can be found in Tables 7 and 8). With the exception of the returns data, the underlying data have been detrended by taking the logarithm and applying the Hodrick-Prescott filter with a smoothing parameter of 1,600. As shown in Figure 1, the returns to the S\&P 500 are occasionally negative, so the usual business cycle detrending procedure cannot be applied. Instead, returns are expressed as a percentage deviation from their sample averages, a procedure that is in the same spirit as the Hodrick-Prescott filter.

On the real side, the benchmark economy's performance is similar to that of other RBC models. Models calibrated to the observed Solow residual process typically underpredict the volatility of output; so does our model. In the data, consumption varies less than output, while investment varies more; our model delivers this ranking but underpredicts the volatility of consumption while exaggerating that of investment.

In the U.S. economy, the return to capital is 6.3 times more volatile than output and is procyclical. The S\&P 500 return, however, is far more volatile than output-155 times more. As reported in Table 4, the model predicts that the return to capital is 3.7 times more volatile than output and is strongly procyclical. In the data, the return to capital is 6.3 times more volatile than output, so the model captures roughly 60 percent of the relative volatility of the return to capital. If the target is the volatility of the S\&P 500 return, the model does quite poorly, capturing less than 3 percent of this relative variability. 


\section{Table 5}

\section{Quantitative Implications of Higher Risk Aversion}

\begin{tabular}{|c|c|c|c|c|c|c|}
\hline & \multicolumn{3}{|c|}{ U.S. 1954:Q1-2015:Q1 } & \multicolumn{3}{|c|}{ High risk-aversion model } \\
\hline & $\begin{array}{l}\text { Percent } \\
\text { standard } \\
\text { deviation }\end{array}$ & $\begin{array}{l}\text { Relative } \\
\text { standard } \\
\text { deviation }\end{array}$ & $\begin{array}{l}\text { Correlation } \\
\text { with output }\end{array}$ & $\begin{array}{c}\text { Percent } \\
\text { standard } \\
\text { deviation }\end{array}$ & $\begin{array}{l}\text { Relative } \\
\text { standard } \\
\text { deviation }\end{array}$ & $\begin{array}{l}\text { Correlation } \\
\text { with output }\end{array}$ \\
\hline Output & 1.72 & 1.00 & 1.00 & 1.22 & 1.00 & 1.00 \\
\hline Consumption & 0.94 & 0.55 & 0.82 & 0.76 & 0.62 & 1.00 \\
\hline Investment & 4.90 & 2.85 & 0.90 & 4.05 & 3.37 & 1.00 \\
\hline Hours & 1.83 & 1.06 & 0.83 & 0.34 & 0.28 & 1.00 \\
\hline Productivity & 1.04 & 0.60 & 0.19 & 0.87 & 0.72 & 1.00 \\
\hline Capital & 1.40 & 0.81 & 0.26 & 0.26 & 0.21 & 0.00 \\
\hline Return to capital & 10.79 & 6.27 & 0.36 & 7.58 & 6.26 & 0.42 \\
\hline
\end{tabular}

\section{Table 6}

\section{Quantitative Implications of Indivisible Labor}

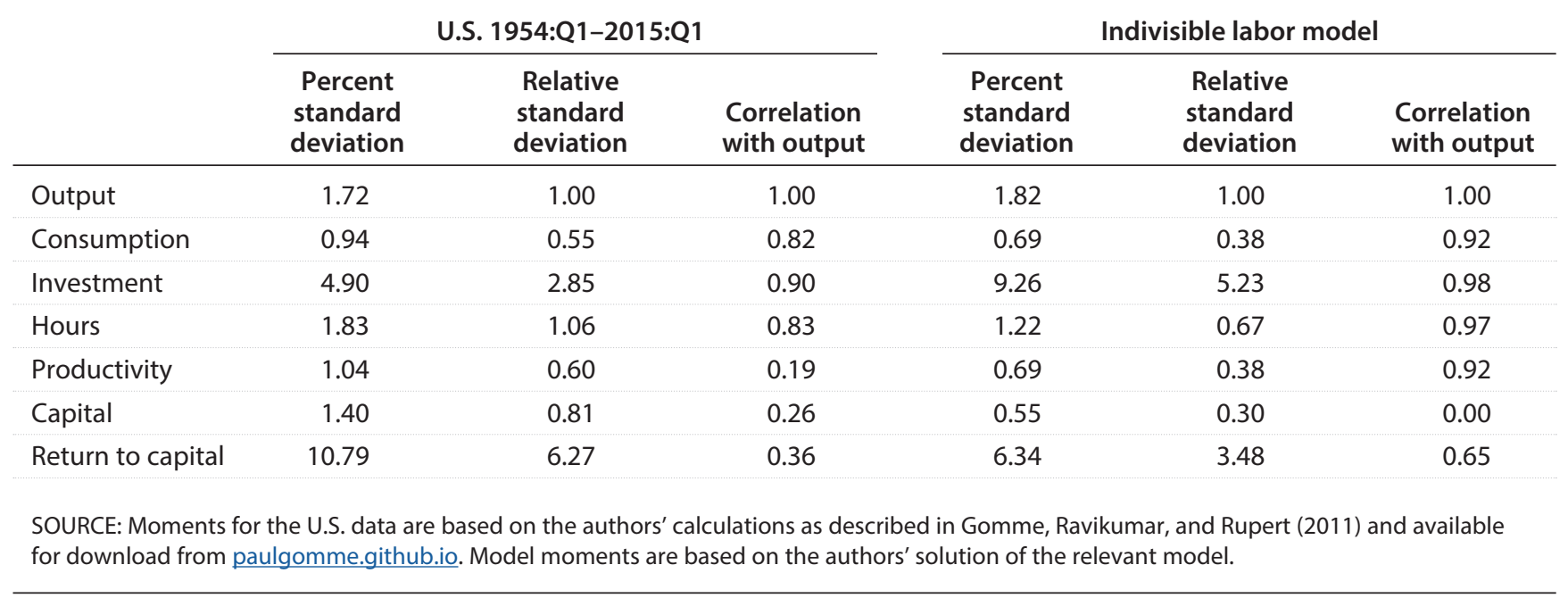

\subsection{Alternative Models and Parameterizations}

In this subsection, we consider two variants on the benchmark model. The common theme is to explore the model's implications for the volatility of the return to capital. As motivation for these experiments, consider the intertemporal equation governing the accumulation of capital:

$$
1=E_{t}\left\{\left(\beta \frac{U_{c, t+1}}{U_{c, t}}\right)\left[1+\alpha\left(\frac{y_{t+1}}{k_{t+1}}\right)-\delta\right]\right\} .
$$


The idea here is to consider alternative models or parameterizations that affect the second term, the gross return to capital, either directly or indirectly through the first term, which is the stochastic discount factor or the intertemporal marginal rate of substitution for consumption.

The first model variant increases the coefficient of relative risk aversion, $\gamma$, from 1 to 5 . As we change $\gamma$, the model is recalibrated to match the targets discussed in Section 4.1. This change has two important implications. First, utility is no longer additively separable between consumption and leisure, which implies that the intertemporal marginal rate of substitution now depends not only on consumption but also on leisure (hours worked). Second, the representative household will have a stronger utility-smoothing motive as $\gamma$ increases. ${ }^{4}$ Increasing risk aversion raises the volatility of the return to capital (as reported in Tables 5 and 9). In this case, the model predicts that the return to capital relative to output is as volatile as seen in the data; the relative standard deviation in both cases is 6.3. For the most part, this improvement does not come at the cost of substantially worsening the model's predictions for the real side of the economy.

The second model variant considers Hansen (1985)-Rogerson (1988) indivisible labor, again recalibrating the model. This variant operates more on the return-to-capital term in equation (16). Whereas the benchmark model in Section 2 allows for a continuous choice over hours worked, indivisible labor restricts the choice of hours to be a positive constant (e.g., a 40-hour work week) or zero. Rogerson showed that employment lotteries are welfareimproving and that the planner's preferences have a much higher labor-supply elasticity than the representative household. In fact, for Hansen's choice of logarithmic preferences, the planner's labor-supply elasticity is infinite. Quantitatively, Hansen showed that indivisible labor could substantially increase the volatility of hours worked. If the variability of capital is not much affected by the introduction of indivisible labor, then we might expect to see more volatility in the marginal product of capital, and so also in the return to capital; to see this, rewrite equation (16) as

$$
1=E_{t}\left\{\left(\beta \frac{U_{c, t+1}}{U_{c, t}}\right)\left[1+\alpha\left(\frac{z_{t+1} h_{t+1}}{k_{t+1}}\right)^{1-\alpha}-\delta\right]\right\} .
$$

Relative to the benchmark model, introducing indivisible labor increases the volatility of macroaggregates-just as in Hansen. However, relative to output, the volatility of the return to capital in the indivisible labor economy is 3.5 which is lower than the 3.7 found for the benchmark calibration (compare Tables 4 and 8 with Tables 6 and 10).

\section{CONCLUSIONS}

We constructed a time series for the return to capital and showed that its behavior is substantially different from the S\&P 500 return. Our measure of the return to capital is considerably smoother (by a factor of 25) and has a lower mean. The standard real business cycle model with logarithmic preferences accounts for close to 60 percent of the observed volatility in the return to capital relative to the volatility of output. We considered two variants of the 


\section{Gomme, Ravikumar, Rupert}

standard model-high risk aversion and indivisible labor. The high-risk-aversion model delivers 100 percent of the relative volatility in the return to capital; the indivisible labor model delivers about 55 percent.

To date, the literature has focused on "fixing" the standard RBC model to account for the business cycle properties of the S\&P 500 return. From a theoretical point of view, there is no reason to prefer the S\&P 500 return over the return to capital as computed in this article because the two returns are theoretically equivalent. As is evident from Figure 1, in order to simultaneously account for the volatilities of the return to capital and the S\&P 500 return, we have to break the equivalence in the model between the return to capital and the return to equity. To the extent that the S\&P 500 return does not reflect the return on a representative unit of capital in aggregate models (see Mulligan, 2002, for instance), it might be useful to construct a general equilibrium theory of publicly traded firms and of "non-traded" firms. Another approach to break the equivalence might be to introduce limited participation in equity markets.

\section{Table 7}

\section{U.S. 1954:Q1-2015:Q1: Selected Moments}

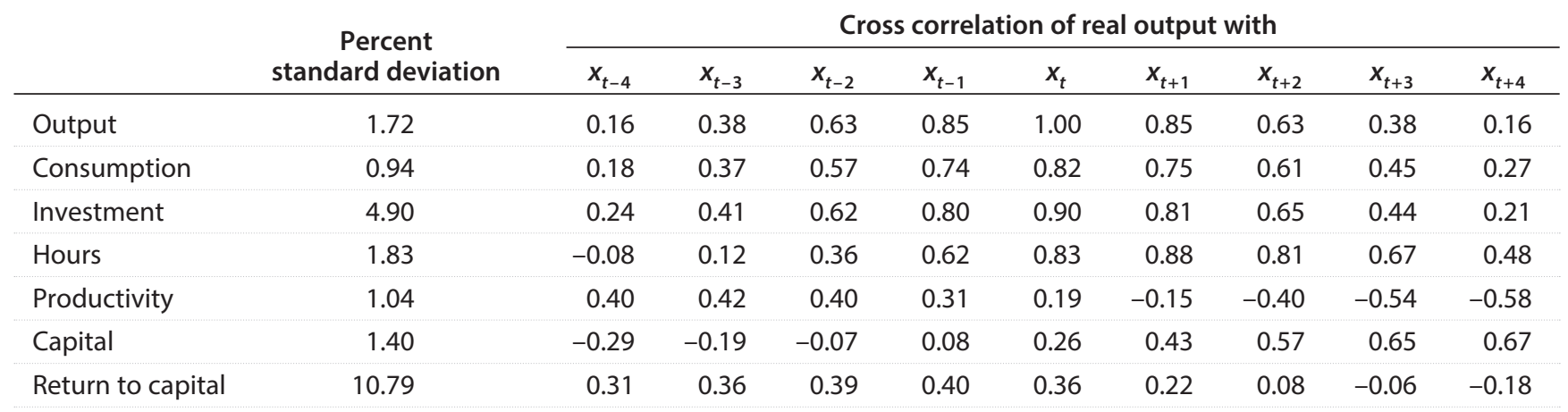

SOURCE: Moments for the U.S. data are based on the authors' calculations as described in Gomme, Ravikumar, and Rupert (2011) and available for download from paulgomme.github.io. 


\section{Table 8}

\section{Benchmark Real Business Cycle Model: Selected Business Cycle Moments}

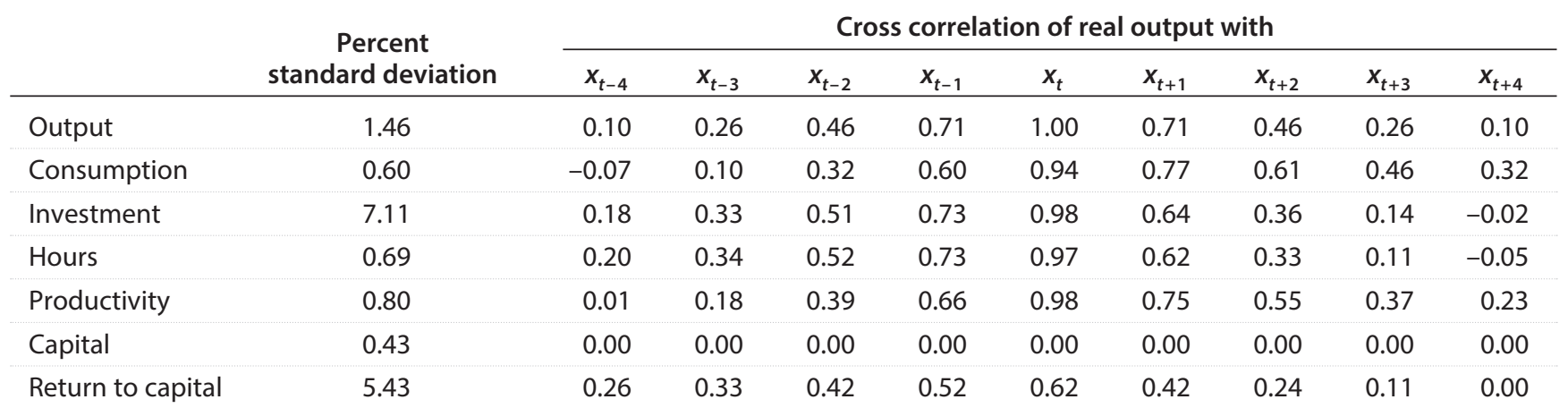

SOURCE: Model moments are based on the authors' solution of the relevant model.

\section{Table 9}

High Risk-Aversion Model: Selected Business Cycle Moments

\begin{tabular}{|c|c|c|c|c|c|c|c|c|c|c|}
\hline & \multirow{2}{*}{$\begin{array}{c}\text { Percent } \\
\text { standard deviation }\end{array}$} & \multicolumn{9}{|c|}{ Cross correlation of real output with } \\
\hline & & $x_{t-4}$ & $x_{t-3}$ & $x_{t-2}$ & $x_{t-1}$ & $x_{t}$ & $x_{t+1}$ & $x_{t+2}$ & $x_{t+3}$ & $x_{t+4}$ \\
\hline Output & 1.22 & 0.10 & 0.26 & 0.46 & 0.71 & 1.00 & 0.71 & 0.46 & 0.26 & 0.10 \\
\hline Consumption & 0.76 & 0.08 & 0.24 & 0.44 & 0.70 & 1.00 & 0.72 & 0.48 & 0.29 & 0.13 \\
\hline Investment & 4.05 & 0.13 & 0.28 & 0.48 & 0.72 & 1.00 & 0.69 & 0.44 & 0.23 & 0.07 \\
\hline Hours & 0.34 & 0.14 & 0.29 & 0.49 & 0.72 & 1.00 & 0.68 & 0.43 & 0.22 & 0.05 \\
\hline Productivity & 0.87 & 0.08 & 0.25 & 0.45 & 0.70 & 1.00 & 0.72 & 0.47 & 0.28 & 0.12 \\
\hline Capital & 0.26 & 0.00 & 0.00 & 0.00 & 0.00 & 0.00 & 0.00 & 0.00 & 0.00 & 0.00 \\
\hline Return to capital & 7.58 & 0.17 & 0.22 & 0.28 & 0.35 & 0.42 & 0.30 & 0.20 & 0.11 & 0.04 \\
\hline
\end{tabular}

SOURCE: Model moments are based on the authors' solution of the relevant model.

\section{Table 10}

Indivisible Labor Model: Selected Business Cycle Moments

\begin{tabular}{|c|c|c|c|c|c|c|c|c|c|c|}
\hline & \multirow{2}{*}{$\begin{array}{c}\text { Percent } \\
\text { standard deviation }\end{array}$} & \multicolumn{9}{|c|}{ Cross correlation of real output with } \\
\hline & & $x_{t-4}$ & $x_{t-3}$ & $x_{t-2}$ & $x_{t-1}$ & $x_{t}$ & $x_{t+1}$ & $x_{t+2}$ & $x_{t+3}$ & $x_{t+4}$ \\
\hline Output & 1.82 & 0.09 & 0.25 & 0.45 & 0.70 & 1.00 & 0.70 & 0.45 & 0.25 & 0.09 \\
\hline Consumption & 0.69 & -0.10 & 0.07 & 0.29 & 0.57 & 0.92 & 0.77 & 0.62 & 0.48 & 0.35 \\
\hline Investment & 9.26 & 0.17 & 0.32 & 0.50 & 0.72 & 0.98 & 0.63 & 0.35 & 0.13 & -0.03 \\
\hline Hours & 1.22 & 0.19 & 0.34 & 0.51 & 0.73 & 0.97 & 0.61 & 0.32 & 0.10 & -0.06 \\
\hline Productivity & 0.69 & -0.10 & 0.07 & 0.29 & 0.57 & 0.92 & 0.77 & 0.62 & 0.48 & 0.35 \\
\hline Capital & 0.55 & 0.00 & 0.00 & 0.00 & 0.00 & 0.00 & 0.00 & 0.00 & 0.00 & 0.00 \\
\hline Return to capital & 6.34 & 0.26 & 0.34 & 0.43 & 0.54 & 0.65 & 0.43 & 0.24 & 0.09 & -0.02 \\
\hline
\end{tabular}

SOURCE: Model moments are based on the authors' solution of the relevant model. 


\section{Gomme, Ravikumar, Rupert}

\section{NOTES}

1 These figures are in the spirit of "deviations from trend" calculations of other business cycle variables. That is, if $\bar{R}$ is the mean return in the sample and $\hat{R}_{t}=\frac{R_{t}-\bar{R}}{\bar{R}}$ is the deviation at time $t$ from the mean, then the percent standard deviation of the return we report is 100 times the standard deviation of $\hat{R}_{t}$.

$\underline{2}$ Technological growth is omitted to ease the presentation but can easily be introduced.

3 S\&P 500 capital is less than 40 percent of total private fixed capital in the U.S. economy.

4 To the extent that introducing habit persistence has effects similar to increasing risk aversion, this experiment is suggestive of the likely effects of introducing habit.

\section{REFERENCES}

Boldrin, M.; Christiano, L. J. and Fisher, J.D. "Habit Persistence, Asset Returns, and the Business Cycle." American Economic Review, 2001, 91(1), pp. 149-66; https://doi.org/10.1257/aer.91.1.149.

Cooley, T. and Prescott, E.C. "Economic Growth and Business Cycles," in T. Cooley, ed., Frontiers of Business Cycle Research. Princeton: Princeton University Press, 1995, pp. 1-38.

Gomme, P.; Ravikumar, B. and Rupert, P. “The Return to Capital and the Business Cycle." Review of Economic Dynamics, 2011, 14(2), pp. 262-78; https://doi.org/10.1016/j.red.2010.11.004.

Gomme, P. and Rupert, P. "Theory, Measurement, and Calibration of Macroeconomic Models." Journal of Monetary Economics, 2007, 54(2), pp. 460-97; https://doi.org/10.1016/j.jmoneco.2005.09.005.

Hansen, G.D. "Indivisible Labor and the Business Cycle." Journal of Monetary Economics, 1985, 16(3), pp. 309-27; https://doi.org/10.1016/0304-3932(85)90039-X.

Klein, P. "Using the Generalized Schur Form to Solve a Multivariate Linear Rational Expectations Model." Journal of Economic Dynamics and Control, 2000, 24(10), pp. 1405-23; https://doi.org/10.1016/S0165-1889(99)00045-7.

Mulligan, C.B. “Capital, Interest, and Aggregate Intertemporal Substitution.” NBER Working Paper No. 9373, National Bureau of Economic Research, 2002.

Rogerson, R. "Indivisible Labor, Lotteries and Equilibrium." Journal of Monetary Economics, 1988, 21(1), pp. 1-16; https://doi.org/10.1016/0304-3932(88)90042-6. 